of the British, poor linguists that they still are, become more European in outlook when exposed to high concentrations of 'forcign' colleagues.

The last chapter, by the late R. David Gillespie, is devoted to the politics of cybernetics in the Soviet Union. Norbert Wiener's pioneering ideas of the forties first ran foul of the Great Scientist's henchman, Zhdanov, on grounds based partly on the orthodoxies of dialectical materialism, and partly on the not-invented-here syndrome. Later, cybernetics became part of Soviet orthodoxy. In the words of David Lerner's introduction, "Gillespie charts the shift of official policy from dogged antagonism to euphoric embrace". This is a piece of very solid detailed politicoscientific history.

In the postface (this must be one of the few nearly Latin words invented in the twentieth century!), Eugene Skolnikoff outlines the increasing involvement, since the Second World War, of MIT in the field of science and public policy.

Overall, these essays, which although properly quantitative in approach are refreshingly clear and free of sociological jargon, go down as easily as a dish of oysters. In consuming them, however, one should carefully extract the pearls of wisdom which one will certainly encounter in the process.

RoBert CAHN

\section{Statistics in ferment}

Theory of Probability: A Critical Introductory Treatment. Vol. 1. By Bruno de Finetti. Translated by Antonio Machi and Adrian Smith. Pp. xix +300 . (Wiley Series in Probability and Mathematical Statistics.) (Wiley: London and New York, April 1974.) £7.50.

THE foundations of statistics are in dispute, and have been for many years. Scientists for the most part think they need-and believe they can have-an objective language of statistics by which they can evaluate and communicate their results. Usually they use significance tests, estimation procedures, and confidence intervals, and are happy to overlook the fact that most enquirers into the logical basis of this so-called 'repeated-sampling' methodology have concluded that it is unsound. R. A. Fisher, geneticist as well as statistician, H. Jcffreys, geophysicist, and I. Hacking, philosopher, have been three outstanding critics. Fisher, on whose early work much of the repeated-sampling development relies, was fulsome in his condemnation of later developments, and in Statistical Methods and Scientific Inference (1956) sought to stem the tide, allowing, apart from the simple test of significance, only those repeated- sampling methods which he thought made full use of all the information in the sample. Not only was he unable to provide a unitary method for statistical inference: he formed the opinion that no such method was possible. Jeffreys, who had never regarded the repeated-sampling theory as more than a passing aberration, developed in Theory of Probability (1939), an account of the objective Bayesian theory, in which the probabilities of hypotheses are modified by the likelihood obtained from experimental results, according to Bayes' Theorem. Hacking, surveying the whole field in 1965 in Logic of Statistical Inference, opined that there was much sense in what both Fisher and Jeffreys had to say, especially in criticism of the repeated-sampling theory, and concluded that the one element common to both their philosophiesthe likelihood-could be elevated into a method in its own right, and, furthermore, that it could be cxtended a little into the repcated-sampling domain to give a satisfactory explication of the core of Fisher's fiducial theory and Jeffreys's theory for the estimation of location and scale parameters.

As if this was not controversy enough, there are those who say that an objective theory of scientific data analysis and reporting is impossible (and who can blame them for pointing to the existing confusion as evidence?). Though the point of view has its origins in the writings of J. M. Keynes and F. P. Ramsey, its principal exponents have been L. J. Savage (The Foundations of Statistics, 1954) and Professor Bruno de Finetti. In the present volume the latter offers the first half of his "necessary document for clarifying one point of vicw in its entirety" - the subjective Bayesian point of view. The work was first published in Italian in 1970, and for English readers has been divided into two (as well as being most admirably translated).

Nobody should attempt to judge this work without prolonged reflection. It must be bought, read, and then left lying around so that it can be assimilated over the years. No book on statistical inference and the foundations of probability ever persuaded anybody directly, for we all make up our own minds by subjecting them to a thousand subtle influences. Only once we are persuaded do we see the virtues of a clear and logical development; Professor D. V. Lindley may be cited as an example, for he writes, in a foreword to this volume, 'that it is a book destined ultimately to be recognised as one of the great books of the world' A reviewer, mindful of Pascal's wager, might be well advised to agree; but I have my doubts. De Finetti's volume 1 presents only half his case, and since his discussion of inductive reasoning and statistical inference is not reached until towards the end of volume 2, we must bide our time. What is already certain, however, is that de Finetti is giving a mastcrly clarification of 'one point of vicw in its entirety', raising the level of discussion to unsurpassed heights. I await volume 2 with impatience.

A. W. F. EDWARDS

\section{Population structure}

Methods and Theories of Anthropological Genetics. Edited by M. H. Crawford and P. L. Workman. Pp. xviii +509 . (A School of American Research Book.) (University of New Mexico: Albuquerque, December 1973.) \$20.

What can 'anthropological genetics' be? That part of genetics pertaining to man, usually called human genetics? No, this book is really about genetical anthropology, or that part of anthropology whose study is made more fruitful by an appeal to genetical principles and genetical information, a sibling of social anthropology and physical anthropology. In particular it is the study of population structure and population relatedness using models and methods devcloped by geneticists, and gene frequencies as a primary source of information. It arose because of the conjunction of a vast increase in the amount of genetic information available and the advent of electronic computing, and has particular topicality because of the modern discussion of racial differences.

About ten years ago some geneticists with a mathematical bent started applying their techniques to some of the problems of anthropology, and began developing new techniques appropriate to the computer age. Although anthropologists had earlier assimilated the pionecring work on the distribution of the human blood groups, they tended to regard this incursion with suspicion, but soon came to terms with the new approach. The success of the invaders owed much to the fact that not only did the geneticists bring their own tools: they also brought a wide range of statistical and computational expertise that was, for the most part, new to anthropology.

This volume is a revised and extended report of a conference held in early 1971 , and consists of nineteen papers (the last being a useful review of the remainder) followed by nearly six hundred references. These are interesting in themselves: a histogram for the years of publication shows a close fit to an exponential rate of increase with a doubling time of five years (20 in 1960 , 40 in 1965, 80 in 1970), and is an indication of the impossibility of being really up to date with such a book. 